\title{
EDUKASI MASYARAKAT TENTANG COVID-19 DI KELURAHAN NEGERI JAYA KECAMATAN NEGERI BESAR KABUPATEN WAY KANAN
}

https://doi.org/10.33024/jkpm.v4i6.4941

\author{
M. Arifki Zainaro ${ }^{1}$ Fara Millinia Suwares ${ }^{2 *}$ \\ Perogram Studi Ilmu Keperawatan Universitas Malahayati Bandar Lampung \\ Disubmit: 27 Agustus $2021 \quad$ Diterima: 09 September 2021 Diterbitkan: 01 Desember 2021 \\ Email Korespondensi: faramilliniasuwares20@gmail.com
}

\begin{abstract}
ABSTRAK
Coronavirus Disease 2019 (COVID-19) adalah jenis penyakit baru yang sebelumnya belum teridentifikasi pada manusia. Dan semakin banyaknya lonjaka angka positif virus corona di Indonesia, sepatutnya menaikkan pemahaman penduduk terhadap bahaya pandemi ini. Rencana dari kegiatan yang dilakukan ini adalah agar masyarakat biasa tau apa itu pengertian dari COVID-19 dan meningkatkan kesadaran akan pentingnya sikap masyarakat terhadap orang-orang yang Terinfeksi Virus COVID-19 baik itu dirinya, keluarga ataupun tetangganya, dan tujuan dari kegiatan khusus ini adalah untuk dapat mengatasi sikap masyarakat terhadap orang-orang yang Terinfeksi Virus COVID-19 secara mandiri dengan memberikan edukasi/informasi tentang COVID-19 setelah dilakukan kegiatan penyuluhan. Sebelum dilakukan kegiatan edukasi diketahui pengetahuan masyarakat hanya sekitar 60\%. Kemudian dilakukan edukasi singkat menggunakan aplikasi Zoom dan Power Point terdapat peningkatan $80 \%$ kemampuan dan pengetahuan tentang COVID-19 dan bagaimana cara menyikapinya jika ada seseorang yang terinfeksi COVID-19 pada masyarakat kelurahan Negeri Jaya kecamatan Negeri Besar kabupaten Way Kanan.
\end{abstract}

Kata Kunci : COVID-19, Edukasi, Meningkatkan Kesadaran, Sikap Masyarakat.

\begin{abstract}
Coronavirus Sickness 2019 (COVID-19) is a novel form of disease that has never been seen in humans before. Furthermore, the rising number of corona virus positives in Indonesia should raise public awareness of the pandemic's hazards. The goal of this activity is for ordinary people to understand what COVID-19 means and to raise awareness of the importance of public attitudes toward people infected with the COVID-19 virus, whether they are themselves, their families, or their neighbors. The goal of this special activity is to be able to overcome public attitudes toward people infected with the COVID-19 virus independent of the COVID-19 virus. Only approximately $60 \%$ of the public was aware of the instructional initiatives before they were implemented. Then, using the Zoom and Power Point apps, a brief education was performed in the Negeri Jaya sub-district, Negeri Besar sub-district, and Way Kanan district, resulting in an 80 percent improvement in ability and knowledge of COVID-19 and how to respond if someone was infected with COVID-19.
\end{abstract}

Keywords : COVID-19, Education, Public Awareness, and Community Attitudes 


\section{PENDAHULUAN}

Coronavirus Disease 2019 (COVID-19) iyalah penyakit jenis baru serta sampai saat ini belum ada pada manusia sebelum nya. Virus pemicu COVID19 ini dinamakan SarsCoV-2. Virus corona merupakan zoonosis yaitu (menular atara binatang dan juga manusia). Dan ada juga beberapa penelitian memberitahu bahwa SARS diteruskan dari luak kekucing di sebut juga civet cats ke kemanusia serta MERS berasa dari unta kemanusia(Kementerian Kesehatan, 2020). Ciri-ciri dari tanda infeksi COVI-19 adalah demam, gangguan pernafasan kronis, batuk dan juga mulut tidak dapat merasakan rasa seta hidung tidak dapat mencium bau. masa inkubasi virus COVID-19 bisa sampai 12-14 hari paling lama.Kasus ini paling parah dapat menyebabkan sindrom pernafasan kronik, gagal ginjal, pneumonia dan paling parahnya lagi dapat menyebabkan kematian. Serta gejala klinis yang sampai saat ini dilaporkan dengan sebagian besar adalah kesulitan bernafas, demam serta hasil rontgen menujukan infiltrt pneumonia yang besar di bagian paru-paru (Kementrian kesehatan,2020).

Secara epidemiologis, prevalensi penyakit COVID-19 menaik sangat tinggi di seluruh dunia. WHO sudah mengungkapkan COVID-19 adalah pandemic sedunia. Kasus COVId-19 yang pertama kali ditemukan pada bulan Desember tahun 2019 di Wuhan Negara Cina. Setelah itu dalam seminggu hingga bulan menyebar sangat cepat di berbagai negara lain seperti italia amerika serikat dan jerman (Zhou F,Yu T,Du R,Fan G,Liu Y, Liu Z, 2020).

Munculnya berita dan sikap ketidaktahuan dari warga tidak terlalu mengejutkan Hadiswi (2016) Pengetahuan kesehatan yg tidak baik, di tambah lagi dengan minimnya sinergi dan minimnya pengetahuan tentang wabah COVID-19 mengakibatkan penanganan wabah tersebut tersendatsendat oleh pemerintah. (Ghani, 2020). Saat ini, pemerintah melakukan berbagai upaya untuk menangani COVID-19, penangatan tersebut berupa sosialisasi tentang pengetahuan, pencegahan serta meningkatkan pelayanan kesehatan yang berhubungan dengan COVID-19. Berita yang digunakan dengan cepat dapat mendukung pentingnya dalam system kesehatan, sangat penting jika ada informasi yang bias di andalkan terkait COVID-19.

Hanya karena seseorang telah terinfeksi virus Corona COVID-19 bukan berarti akan menjadi sakit lagi. Karantina mandiri bertujuan untuk mengembangkan mereka yang terpapar dari orang sehat, yang tidak menularkan penyakit jika terinfeksi COVID-19. Karena setiap orang yang saat ini tinggal di rumah mereka cenderung memiliki lebih banyak waktu untuk terlibat dalam komunikasi tatap muka atau jarak jauh dengan orang lain. Seseorang jika terinfeksi bisa menyebarkan virus walaupun tidak bergejala dapat diketahui, tetapi ahli tidak tahu sebagian besar kemungkinan seseorang yang sudah terinfeksi COVID-19 dapat menginfeksi orang lain, serta kapan virus tersebut menjadi menular. Karena ini kenapa sangat penting bahwa warga jika terpapar membatasi diri kontak langsung sama seseorang lain dan orang yang berada di rumah. 
Dari berbagai alasan dan permasalahan tersebut, jadi saya sangat tertarik untuk melakukan pengabdian kepada masyarakat dengan judul Eduksi Masyarakat Tentang COVID-19 Di kelurahan Negeri Jaya Kecamatan Negeri Besar Kabupaten way kanan.

\section{MASALAH}

1. Alasan saya Kkl-Ppm Di Kelurahan Negeri Jaya Kecamatan Negeri Besar Kabupaten Way Kanan. Karena tahun 2021 tidak ada kegiatan langsung ke lokasi dan saat ini banyaknya kasus positif di Desa Negeri Jaya. Selain itu fasilitas kesehatan yang ada di Desa Negeri Jaya belum memadai untuk penanganan terkait kasus COVID-19, serta masih banyak orang yang tidak peduli dengan keberadaan COVID-19 dan banyak masyarakat yang tidak mematuh protocol kesehatan sehingga meningkat kasusu COVID-19 di Desa Negeri Jaya. Serta tujuan khusus pendidikan dan edukasi singkat ini adalah meningkatkan pemahaman tentang definisi istilah COVID-19, dan pemahaman kepada masyarakat bagaiamana cara mengatasi sikap masyarakat jika dirinya dan keluarga terinfeksi COVID-19.



Gambar 2.1 Peta Lokasi PKM.

\section{METODE}

a. Tujuan Perencanaan

Tahapnya yaitu membuat pra perencanaan, persiapan penyajian power point dan laptop ataupun handphone karena akan melakukan edukasi online melalui aplikasi zoom bersama warga desa Negeri Jaya.Pembuatan Power point dimulai pada hari Rabu 28 Juli 2021, pada hari Kamis 29 Agustus dilakukan pengecekan untuk persiapan edukasi singkat dalam bentuk pengecekan power point.

b. Tahap pelaksanaan

Tahap pelaksanaan acara, dengan memberitahukan kepeserta selama melakukan kegiatan penyuluhan secara online sesuai jadwal yang di tentukan penyuluhan ini dilakukan secara online karena pada masa pandemi COVID-19. 


\section{c. Evaluasi}

1) Struktur

Seluruh Peserta yang dating sudah sesuai dengan waktu dan jadwal yang di tentukan, peralatan dan bahan sudah di buat sebagimana mestinya untuk di pergunakan dalam edukasi singkat tentang Covid, penggunaan kata-kata yang tepat dan benar dapat mempermudah audiens mengerti materi yang di berikan.

2) Peroses

Pelaksanaan acara dilakukan dipukul 15.00-16.30 WITA. Sesuai dengan jadwal yang sudah telah ditentukan dan diberitahukan sebelumnya.

\section{HASIL DAN PEMBAHASAN}

Metode pelaksanaanya dalam kegiatan penyuluhan kesehataan tentang COVID-19 pada hari Sabtu 31 Juli 2021 di kediaman masing-masing secara virtual menggunakan aplikasi zoom. Pelaksanaan penyuluhan ini ditujukan kepada peserta Desa Negeri Jaya yang belum memahami tentang COVID-19. Alat-alat yang digunakan berupa power point dan elektronik yang di gunakan untuk zoom. Metode yang di gunakan ceramah, tanya jawab dengan menjelaskan tentang definisi istilah COVID-19, dan bagaiamana cara mengatasi sikap masyarakat jika dirinya dan keluarga terinfeksi COVID-19. Dari hasil penyuluhan diketahui terdapat kemajuan pada peserta penyuluhan sekitar $80 \%$. Pada saat sebelum dilakukan penyuluhan persentase pengetahuan peserta penyuluhan hanya 60\% mengenai COVID-19.

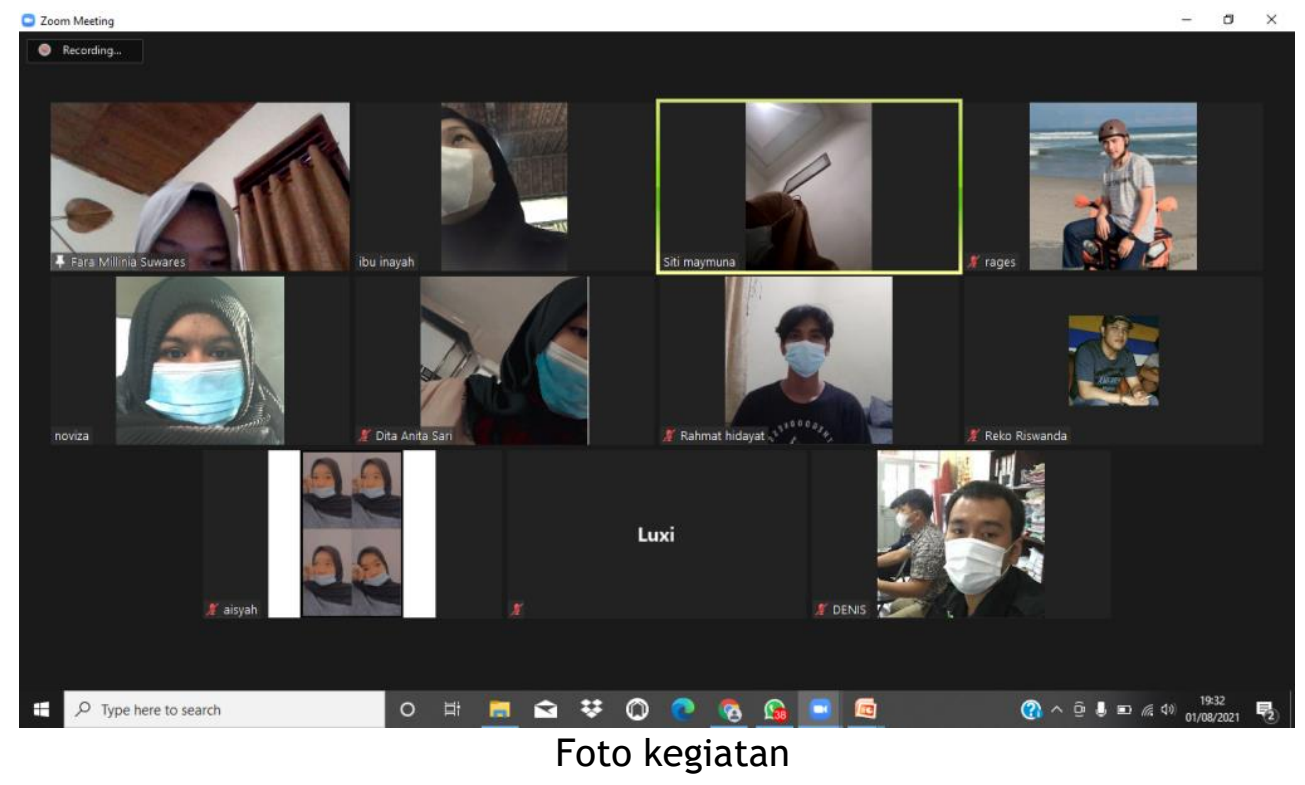

\section{KESIMPULAN}

Coronavirus disease 2019 merupakan jenis penyakit yang sangat baru serta tidak teridentifikasi sama sekali pada manusia. system pernafasan. Virus corona biasanya menimbulkan beberapa masalah ringan pada system pernapasannya, infeksi paru-paru yang sangat parah, dan paling parahnya lagi dapat menyebabkan kematian.

Penyuluhan singkat ini bertujuan untuk dapat mengetahui definisi istilah COVID-19 serta meningkatkan kesadaran akan pentingnya sikap masyarakat 
dengan warga yang Terinfeksi Virus COVID-19 baik itu dirinya keluarga ataupun tetangganya. Kegiatan penyuluhan edukasi singkat ini merupakan salah satu bentuk kegiatan positif yang harus saangat-sangat di kembangkan karena dapat bermanfaat kepada warga serta bias melaksanakan dengan kehidupan sehari-harinya terutama jika dirinya, keluarganya serta tetangganya terinfeksi COVID-19.

\section{DAFTAR PUSTAKA}

Ghani, M. W. (2020).. Mengelola Pengetahuan COVID-19 dengan Konsep Manajemen Pengetahuan.

Lestari, P., \& Handiyani, H. (2017)... Tingkat health literacy mahasiswa kesehatan lebih tinggi dibandingkan mahasiswa non kesehatan.

Masrul, M., Abdillah, L. A., Tasnim, T., Simarmata, J., Daud, D., Sulaiman, O. K., ... \& Faried, A. I. (2020). COVID-19 Pandemic: Issues and Reflections in Indonesia. Our Writing Foundation.

Mubarak, W. (2011). Promosi Kesehatan Masyarakat untuk Kebidanan. Jakarta: Salemba Medika.

Permenkes, R. (2014). Pedoman Gizi Seimbang. In: Peraturan Menteri Kesehatan Republik Indonesia Nomor Puskesmas Kapita Kabupaten Jeneponto. Uin Alauddin Makassar.

Sari, E.P.P., Furwasyih, D., \& Riyantori, R. (2021). Tingkat Pengetahuan Masyarakat Tentang Klasifikasi Kasus Pasien Covid-19 Jurnal Kesehatan Mercusuar, 4(1), 57-65.

Utama, I. G. B. R., Suamba, I. B. P., Sumartana, I. M., Waruwu, D., \& Krismawintari, N. P. D. (2020). Dampak Himbauan Social Distancing Dalam Mengurangi Penyebaran Covid-19.

WHO. Virus corona disease (COVID-19) outbreak situation. WHO. 2020

WHO. Corona virus disease 2019 ( COVID-19 ): Laporan Situasi - 64. Laporan Situasional Covid-19. 2020.

Zhou F, Yu T, Du R, Fan G, Liu Y, Liu Z, et al. Clinical course and risk factors for mortality of adult inpatients with COVID-19 in Wuhan, China : a retrospective cohort study. Lancet. 2020;6736(20):1-9 